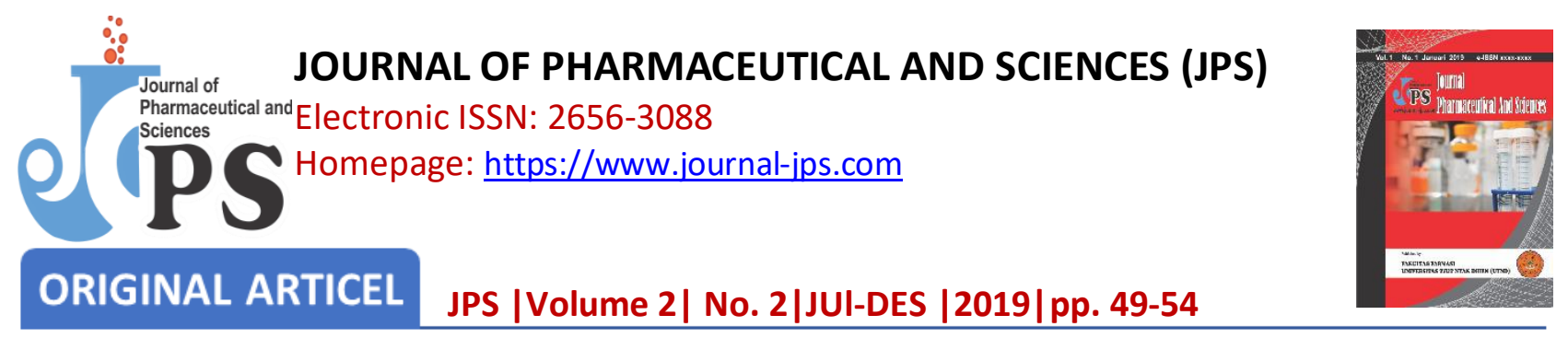

\title{
ANTIBACTERIAL ACTIVITY TEST OF EXTRACT ETHANOL OF JACKFRUIT LEAVES (Arcotarpus heterophyllus Lamk.) OF BACTERIA Staphylococcus aureus, Escherichia coli, Staphylococcus epidermidis AND Salmonella typhi
}

\section{UJI AKTIVITAS ANTIBAKTERI EKSTRAK ETANOL DAUN NANGKA (Artocarpus heterophyllus Lamk) TERHADAP BAKTERI Staphylococcus aureus, Escherichia coli, Staphylococcus epidermis, DAN Salmonella typhi}

\author{
Dameria Siahaan ${ }^{1}$, Kasta Gurning ${ }^{1}$, Iksen $^{1}$ * \\ ${ }^{1}$ Program Studi Sarjana Farmasi \\ Sekolah Tinggi Ilmu Kesehatan (STIKes) Senior Medan, 20131 \\ Email: kastagurning@gmail.com
}

\begin{abstract}
Jackfruit leaves (Artocarpus heterophyllus Lamk.) have health benefits as an antimicrobial. The leaves contain flavonoids, tannins, saponins which act as antimicrobials. The purpose of this study was to study the potential antibacterial activity of ethanol extract of jackfruit leaves (Artocarpus heterophyllus Lamk.) On the bacteria Staphylococcus aureus, Escherichia coli, Staphylococcus epidermidis, and Salmonella typhi. This research conducted with an experimental method that included the collection and processing of samples, the examination of the simplicia characterization and phytochemical screening. The concentration of jackfruit leaf ethanol extract. Used was at a concentration of $500 \mathrm{mg} \mathrm{mL}, 400 \mathrm{mg} / \mathrm{mL}, 300 \mathrm{mg} / \mathrm{mL}, 200$ $\mathrm{mg} / \mathrm{mL}, 100 \mathrm{mg} / \mathrm{mL}, 100 \mathrm{mg} / \mathrm{mL}, 50 \mathrm{mg} / \mathrm{mL}, 25 \mathrm{mg} / \mathrm{mL}, 10 \mathrm{mg} / \mathrm{mL} 30 \mathrm{mg} / \mathrm{ml}$ chloramphenicol and blanks. Using the disk diffusion method to measure the clear zone against the bacteria Staphylococcus aureus, Escherichia coli, Staphylococcus epidermidis, and Salmonella typhi. Antimicrobial inhibition of ethanol extract of jackfruit leaves against Staphylococcus aureus bacteria at a concentration of $500 \mathrm{mg} / \mathrm{mL}$ has a strong antibacterial inhibition with a diameter of $10.8 \mathrm{~mm}$. The bacteria Escherichia coli, Staphylococcus epidermidis, and Salmonella typhi at a concentration of $500 \mathrm{mg} / \mathrm{mL}$ have inhibitory power, $9.2 \mathrm{~mm}, 9.6 \mathrm{~mm}$, and $8.8 \mathrm{~mm}$ in the medium category. Positive control chloramphenicol has powerful antibacterial inhibition with an inhibition zone diameter of $28.6 \mathrm{~mm}$.
\end{abstract}

Keywords: Jackfruit, staphylococcus aureus, Escherichia coli, staphylococcus epidermidis and Salmonella typhi 


\section{ABSTRAK}

Daun nangka (Artocarpus heterophyllus Lamk.) mempunyai manfaat bagi kesehatan sebagai anti mikroba. Daun nangka mengandung flavonoid, tanin, saponin yang bersifat sebagai antimikroba. Tujuan penelitian ini untuk mengetahui potensi aktivitas antibakteri ekstrak etanol daun nangka (Artocarpus heterophyllus Lamk.) terhadap bakteri Staphylococcus aureus, Escherichia coli, Staphylococcus epidermidis, dan Salmonella typhi. Penelitian ini dilakukan dengan metode eksperimental meliputi pengumpulan dan pengolahan sampel, pemeriksaan karakterisasi simplisia dan skrining fitokimia. Konsentrasi Ekstrak etanol daun nangka (Artocarpus heterophyllus Lamk.) yang digunakan adalah pada konsentrasi $500 \mathrm{mg} / \mathrm{mL}, 400 \mathrm{mg} / \mathrm{mL}, 300$ $\mathrm{mg} / \mathrm{mL}, 200 \mathrm{mg} / \mathrm{mL}, 100 \mathrm{mg} / \mathrm{mL}, 50 \mathrm{mg} / \mathrm{mL}, 25 \mathrm{mg} / \mathrm{mL}, 10 \mathrm{mg} / \mathrm{mL}$ kloramfenikol $30 \mathrm{mg} / \mathrm{ml}$ dan blanko. Menggunakan metode disc diffusion untuk mengukur zona bening terhadap bakteri Staphylococcus aureus, Escherichia coli, Staphylococcus epidermidis, dan Salmonella typhi. Daya hambat antimikroba ekstrak etanol daun nangka (Artocarpus heterophyllus Lamk.) terhadap bakteri Staphylococcus aureus pada konsentrasi $500 \mathrm{mg} / \mathrm{mL}$ memiliki daya hambat antibakteri yang kuat dengan diameter 10,8 mm. Bakteri Escherichia coli, Staphylococcus epidermidis, dan Salmonella typhi pada konsentrasi $500 \mathrm{mg} / \mathrm{mL}$ memiliki daya hambat, $9,2 \mathrm{~mm}, 9,6 \mathrm{~mm}$, dan $8,8 \mathrm{~mm}$ dengan kategori sedang. Kontrol positif yaitu kloramfenikol memiliki daya hambat antibakteri yang sangat kuat dengan diameter zona hambat 28,6 mm.

Kata Kunci: Daun nangka, Staphylococcus aureus, Escheriachia coli Staphylococcus epidermidis dan Salmonella typhi

\section{PENDAHULUAN}

Indonesia merupakan negara kaya tanaman obat. Berbagai jenis tanaman obat tumbuh dengan baik. Tanaman obat tersebut sudah dipakai oleh masyarakat Indonesia, terutama dipedesaan selama beratus-ratus tahun. Sekalipun baru bersifat empiris, tanaman obat tersebut masih dipakai sampai sekarang karena alasan efektifitas biaya dan tingkat keamanan. Salah satu tanaman obat yang memiliki banyak khasiat adalah tanaman nangka (Artocarpus heterophyllus Lamk) (Nasution dkk., 2014).

Pada umumnya, daun nangka dikenal sebagai pakan ternak, tetapi dibalik fungsinya sebagai pakan ternak, daun nangka mempunyai manfaat bagi kesehatan karena daun nangka mengandung anti mikroba antara lain flavonoid, tanin, saponin yang bisa larut dalam air dan dapat bekerja merusak membran sitoplasma dan mendenaturasi protein sel. Bakteri merupakan mikroorganisme yang tidak dapat dilihat oleh mata telanjang, tetapi hanya dapat dilihat dengan bantuan mikroskop. $\mathrm{Di}$ antaranya adalah Staphylococcus aureus, Escherichia coli, Staphylococcus epidermis dan Salmonella typhi (Kusumawati dkk., 2017).

Staphylococcus aureus merupakan salah satu penyebab utama infeksi nosokomial. Selain itu, Staphylococcus aureus juga dapat menyebabkan keracunan makanan, sindrom kulit (melepuh) dan syok toksik melalui produksi berbagai racun (Stark, 2013). Escherichia coli merupakan bakteri gram negatif enterik (Enterobactericeae) yaitu kuman flora normal yang ditemukan dalam usus besar manusia. Bakteri ini bersifat patogen apabila berada diluar usus, yaitu lokasi normal tempatnya berada dan tempat lain yang jarang ditinggali oleh bakteri ini. Escherichia coli sering menimbulkan infeksi pada saluran kemih, saluran empedu dan tempat- tempat lain di rongga perut. Escherichia coli juga merupakan penyebab diare dan infeksi saluran kemih (Suryati dkk., 2017). Escherichia coli merupakan penyebab terbanyak kasus diare akut selain Shigella, Salmonela, dan Vibrio. Di negara berkembang, Escherichia coli menyebabkan 25\% kejadian diare. Escherichia coli juga dapat menyebabkan sepsis, meningitis dan infeksi saluran kemih. Escherichia coli merupakan penyebab 90\% infeksi saluran kemih pada wanita muda dan $80 \%$ infeksi saluran kemih pada anak (Yulianty dkk., 2013).

Staphylococcus epidermidis merupakan salah satu dari banyak mikroorganisme yang hidup di kulit manusia sebagai flora normal. Bakteri Staphylococcus epidermis ini merupakan jenis bakteri berbahaya karena tidak merespon dengan baik terhadap antibiotik seperti penisilin, methicilin dan amoksilin. Gangguang kesehatan lain yang disebabkan oleh bakteri Staphylococcus epidermidis 
ini yaitu bau badan.

Bakteri Staphylococcus epidemidis ini juga penyebab masalah kulit wajah. Salah satu masalah kulit wajah yang sering dijumpai yaitu timbulnya jerawat (Yunikasari dkk., 2016). Salmonella thypi merupakan menjadi resintensi terhadap tiga antibiotik sekaligus yakni kloramfenikol, kontrimoksazol, dan amoksilin yang ditemukan secara luas di India, Pakistan dan Cina serta menyebar ke Timur Tengah. Saat ini banyak masyarakat mulai beralih pada pengobatan tradisional karena tidak memiliki efek samping. Bakteri ini masuk kedalam tubuh manusia melalui makanan dan minumam yang terkontaminasi. Salmonella thypi mampu menyebabkan sejumlah besar infeksi sistemik fokal, septicemia, dan gastroenteritis yang bervariasi secara klinis yaitu dari diare cair sampai disentri (Putri, 2012).

Tujuan penelitian ini untuk mengetahui potensi aktivitas antibakteri ekstrak etanol daun nangka (Artocarpus heterophyllus Lamk) terhadap bakteri Staphylococcus aureus, Escherichia coli, Staphylococcus epidermis, dan Salmonella typhi.

\section{METODE PENELTIAN}

Alat.

Alat yang digunakan dalam penelitian ini terdiri dari autoklaf, aluminium foil, batang pengaduk, blender, batang $L$, bunsen cawan petri, cawan penguap, cakram steril, Erlenmeyer $250 \mathrm{~mL}$, gelas ukur $100 \mathrm{~mL}$, gelas ukur $50 \mathrm{~mL}$, gelas ukur 10 $\mathrm{mL}$, inkubator, jangka sorong, kompor gas, kertas perkamen, kapas steril, oven, ose bulat, penangas air, pinset, vortex, rak tabung, rotary evaporator, sendok tanduk, spatula, sarung tangan steril, timbangan analitik, tabung reaksi, dan vial.

\section{Bahan}

Adapun bahan digunakan dalam penelitian ini adalah daun nangka (Artocarpus heterophyllus Lamk) diperoleh dari Desa Marendal II Kecamatan Patumbak Kabupaten Deli Serdang yaitu aquadest steril, asam sulfat, alkohol 70\%, antibiotik kloramfenikol, besi (III) klorida, bismutt subnitrat, biakan bakteri (Staphylococcus aureus, Escheriachia coli, Staphyloccus epidermidis dan Samonella thypi), dimetil sulfoksida, etanol $96 \%$, etanol $70 \%$, iodium, Nutrient Agar, Natrium klorida fisiologi, natrium hidroksida, potassium iodide dan spiritus.

\section{Preparasi Sampel}

\section{Pembuatan Simplisia}

Sampel daun nangka (Artocarpus heterophyllus Lamk) diperoleh dari Desa Marendal II Kecamatan Patumbak Kabupaten Deli Serdang dalam bentuk segar. Sebanyak $8 \mathrm{Kg}$ daun disortasi basah, selanjutnya dicuci dengan air mengalir. Sampel kemudian dikeringkan dengan cara diaginanginkan. Daun yang sudah kering selanjutnya dihaluskan menggunakan blender hingga diperoleh bentuk simplisia kering sehingga diperoleh serbuk sebanyak 500 gram.

\section{Pembuatan Ekstrak}

Serbuk simplisia diekstraksi dengan cara maserasi dengan menggunakan etanol 96\% Simplisia daun nangka yang telah kering ditimbang sebanyak 500 gram dimasukkan ke dalam toples kaca dan direndam dengan 75 bagian pelarut etanol $96 \%$, ditutup, dibiarkan selama 5 hari terlindungi dari cahaya dengan sesekali diaduk, saring, peras, cuci ampas dengan cairan penyari secukupnya hingga diperoleh 100 bagian, dibiarkan selama 2 hari terlindungi dari cahaya, disaring. Ekstrak yang didapat kemudian diuapkan dengan menggunakan rotary evaporator sampai diperoleh ekstrak etanol kental. Kemudian dihitung persen rendeman.

\section{Skrining Fitokimia}

\section{Pemeriksaan Alkaloid}

Sebanyak $0,5 \mathrm{~g}$ serbuk simplisia ditambahkan $1 \mathrm{ml}$ asam klorida $2 \mathrm{~N}$ dan $9 \mathrm{ml}$ air suling, dipanaskan di atas penangas air selama 2 menit, didinginkan dan disaring. Filtrat dipakai untuk uji alkaloid sebagai berikut :

a) Filtrat sebanyak 3 tetes ditambah dengan 2 tetes larutan pereaksi Mayer akan terbentuk endapan menggumpal berwarna putih/ kuning.

b) Filtrat sebanyak 3 tetes ditambah dengan 2 tetes larutan pereaksi Bouchardat, akan terbentuk endapan berwarna coklat sampai kehitaman.

c) Filtrat sebanyak 3 tetes ditambah dengan 2 tetes larutan pereaksi Dragendroff, akan terbentuk endapan berwarna merah atau jingga. Alkaloid positif jika terjadi endapan atau kekeruhan paling sedikit dua dari tiga percobaan diatas (Sitorus, 2018). 
2. Pemeriksaan Flavanoid

Sebanyak $0,5 \mathrm{~g}$ serbuk simplisia ditambahkan $20 \mathrm{ml}$ air panas, didihkan selama 10 menit dan disaring dalam keadaan panas ke dalam $5 \mathrm{ml}$ filtrate ditambahkan $0,1 \mathrm{~g}$ serbuk magnesium dan $1 \mathrm{ml}$ asam klorid pekat dan $2 \mathrm{ml}$ amil alcohol dikocok, dan dibiarkan memisah. Flavanoida positif jika terjadi warna merah atau kuning jingga pada lapisan amil alkohol (Sitorus, 2018).

\section{Pemeriksaan Tannin}

Sebanyak $0,5 \mathrm{~g}$ serbuk simplisia disari dengan $10 \mathrm{ml}$ air suling lalu disaring, filtratnya diencerkan dengan air sampai tidak berwarna. Larutan diambil sebanyak $2 \mathrm{ml}$ dan ditambahkan 1-2 tetes pereaksi besi (III) klorida 1\%, jika terjadi warna biru atau kehitaman menunjukkan adanya tanin (Sitorus, 2018).

\section{Pemeriksaan Saponin}

Sebanyak 0,5 g serbuk simplisia dimasukkan dalam tabung reaksi, ditambahkan $10 \mathrm{ml}$ air panas, didinginkan kemudian dikocok kuat- kuat selama 10 detik, jika terbentuk buih setinggi 1 sampai $10 \mathrm{~cm}$ yang stabil tidak kurang dari 10 menit dan tidak hilang dengan penambahan 1 tetes asam klorida 2 $\mathrm{N}$ menunjukkan adanya saponin (Sitorus, 2018).

\section{Pemeriksaan Triterpenoid/Steroid}

Sebanyak $1 \mathrm{~g}$ serbuk simplisia dimaserasi dengan $20 \mathrm{ml}$ eter selama 2 jam, disaring selama 2 jam, disaring, filtrat diuapkan dalam cawan penguap dan pada sisanya ditambahkan 20 tetes asam asetat anhidrat dan 1 tetes asam sulfat pekat (Pereaksi Lieberman- Burchard). Apabila terbentuk warna ungu atau merah yang berubah menjadi biru kehijauan menunjukkan adanya steroida (Sitorus, 2018).
Pembuatan Larutan Uji Ekstrak Etanol Daun Nangka

Sebanyak $5 \mathrm{~g}$ ekstrak etanol daun nangka ditimbang, lalu ditambahkan dimetil sulfoksida (DMSO) hingga volume total $10 \mathrm{~mL}$ dan diaduk hingga larut dan didapat dalam konsentrasi ekstrak adalah $500 \mathrm{mg} / \mathrm{mL}$, kemudian dibuat pengenceran selanjutnya sampai diperoleh esktrak dengan konsentrasi $400 \mathrm{mg} / \mathrm{mL}, 300 \mathrm{mg} / \mathrm{mL}, 200 \mathrm{mg} / \mathrm{mL}$, $100 \mathrm{mg} / \mathrm{mL}, 50 \mathrm{mg} / \mathrm{mL}, 25 \mathrm{mg} / \mathrm{mL} 10 \mathrm{mg} / \mathrm{mL}$ Kloramfenikol dan DMSO10\%.

\section{Pengujian Aktivitas Antibakteri Ekstrak Etanol Daun Nangka}

Sebanyak 0,1 $\mathrm{mL}$ inokulum dimasukkan kedalam cawan petri steril, setelah itu dituang media nutrient agar sebanyak $15 \mathrm{~mL}$, selanjutnya cawan digoyang diatas permukaan meja agar media dan suspensi bakteri tercampur rata, dibiarkan hingga memadat. Pada media yang telah padat diletakkan kertas cakram yang telah direndam 15 menit dalam larutan uji ekstrak etanol dengan berbagai konsentrasi. Kemudian diinkubasi dalam inkubator pada suhu $37^{\circ} \mathrm{C}$ selama 24 jam, lalu diukur diameter daerah hambatan (zona bening) disekitar kertas cakram dengan menggunakan jangka sorong.

\section{HASIL DAN PEMBAHASAN}

\section{Skrining Fitokimia}

Berdasarkan hasil skrining fikokimia, dapat dilihat senyawa metabolit sekunder yang terdapat di dalam simplisia dan ekstrak daun nangka adalah flavonoid, tanin, saponin dan steoid/ Triterpen. Senyawa metabolit sekunder seperti senyawa flavonoid, saponin, tanin dan steroid merupakan senyawa kimia yang memiliki potensi sebagai antibakteri (Hafizan, 2016).

\section{Tabel 1. Hasil Skrining Fitokimia Simplisia dan Ekstrak}

\begin{tabular}{|l|l|c|c|}
\hline No & \multicolumn{1}{|c|}{ Golongan Senyawa } & Simplisia & Ekstrak \\
\hline 1. & Alkaloid & - & - \\
\hline 2. & Flavonoid & + & + \\
\hline 3. & Saponin & + & + \\
\hline 4. & Tannin & + & + \\
\hline 5. & Triterpenoid/Steroid & + & + \\
\hline
\end{tabular}


Uji Aktivitas Antibakteri

Berdasarkan Tabel 2. Dapat dilihat bahwa daya hambat antimikroba ekstrak etanol daun (Artocarpus heterophyllus Lamk) terhadap bakteri Staphylococcus aures pada konsentrasi $500 \mathrm{mg} / \mathrm{ml}$, memiliki daya hambat antibakteri yang kuat dengan diameter zona hambat $10,8 \mathrm{~mm}$ dibandingkan pada konsentrasi $400 \mathrm{mg} / \mathrm{ml}, 300 \mathrm{mg} / \mathrm{ml}, 200 \mathrm{mg} / \mathrm{ml}, 100$ $\mathrm{mg} / \mathrm{ml}, 50 \mathrm{mg} / \mathrm{ml}$, dan $10 \mathrm{mg} / \mathrm{ml}$ yang memiliki daya hambat antibakteri yang sedang dengan diameter $9,6 \mathrm{~mm}, 9,2 \mathrm{~mm}, 9,1 \mathrm{~mm}, 8,9 \mathrm{~mm}, 8,5 \mathrm{~mm}, 7,8$ $\mathrm{mm}, 7,1 \mathrm{~mm}$, dan $7,5 \mathrm{~mm}$. Bakteri Escherichia coli, Staphylococcus epidermidiss dan Salmonella typhi pada konsentrasi $500 \mathrm{mg} / \mathrm{ml}, 400 \mathrm{mg} / \mathrm{ml}, 300$ $\mathrm{mg} / \mathrm{ml}, 200 \mathrm{mg} / \mathrm{ml}, 100 \mathrm{mg} / \mathrm{ml}, 50 \mathrm{mg} / \mathrm{ml}$, dan 10 $\mathrm{mg} / \mathrm{ml}$ memiliki daya hambat antibakteri yang sedang dengan diameter zona hambat 9,2 mm, 9,6 $\mathrm{mm}, 8,8 \mathrm{~mm}$. Kontrol positif yaitu kloramfenikol memiliki daya hambat antibakteri yang sangat kuat dengan diameter zona hambat $14,3 \mathrm{~mm}$, sedangkan kontrol negatf dengan menggunakan dimetil sufoksida dapat dikatakan tidak mempunyai daya hambat antibakteri.

Dari hasil penelitian menunjukkan bahwa ekstrak etanol daun nangka lebih efektif terhadap bakteri Staphylococcus aureus dan Staphylococcus epidermidis dibandingkan pada Salmonella typhi, Escheriachia coli. Aktivitas suatu zat antimikroba dalam menghambat pertumbuhan atau membunuh mikrooganisme tergantung pada konsentrasi dan jenisnya. Hal ini terlihat dari diameter hambat ekstrak etanol daun nangka terhadap keempat bakteri uji dengan konsentrasi $500 \mathrm{mg} / \mathrm{ml}$ yang jauh lebih besar bila dibandingkan dengan konsentrasi lainnya.

\section{Tabel 2. Hasil Uji Aktivitas Antibakteri Ekstrak Etanol Daun Nangka Terhadap Bakteri Staphylococcus aureus, Escherichia coli, Staphylococcus epidermidis dan Salmonella typhi.}

\begin{tabular}{|c|c|c|c|c|c|}
\hline No & $\begin{array}{c}\text { Konsentrasi Ekstrak } \\
\text { Etanol Daun Nangka } \\
\text { (mg/ml) }\end{array}$ & \multicolumn{5}{|c|}{ Diameter Zona Hambat (mm) } \\
\hline S. aureus & E. coli & S. epidermidis & S. typhi \\
\hline $\mathbf{1 .}$ & 500 & 10,8 & 9,2 & 9,6 & 8,8 \\
\hline $\mathbf{2 .}$ & 400 & 9,6 & 8,6 & 9,2 & 8,6 \\
\hline $\mathbf{3 .}$ & 300 & 9,2 & 8,3 & 8,9 & 8,4 \\
\hline $\mathbf{4 .}$ & 200 & 9,1 & 7,9 & 8,6 & 8 \\
\hline $\mathbf{5 .}$ & 100 & 8,9 & 7,3 & 8,4 & 7,7 \\
\hline $\mathbf{6 .}$ & 50 & 8,5 & 7,2 & 8,1 & 7,4 \\
\hline $\mathbf{7 .}$ & 25 & 7,8 & 7,1 & 7,7 & 7 \\
\hline $\mathbf{8 .}$ & 10 & 7,5 & 6,7 & 7,1 & 6,2 \\
\hline $\mathbf{9 .}$ & Kloramfenikol & 28,6 & 14,3 & 28,5 & 23,1 \\
\hline $\mathbf{1 0 .}$ & DMSO & 0 & 0 & 0 & 0 \\
\hline
\end{tabular}

Ekstrak etanol daun nangka (Artocarpus heterophyllus Lamk) aktif sebagai antibakteri dikarenakan komponen kimia yang terkandung dalam ekstrak. Berdasarkan skrining fitokimia, ekstrak etanol daun nangka (Artocarpus heterophyllus Lamk) memiliki kandungan senyawa flavonoid, saponin, tannin dan terpenoid/steroid.

Kandungan flavonoid pada ekstrak etanol daun nangka (Artocarpus heterophyllus Lamk) memiliki sifat antibakteri dengan cara menghambat sintesis asam nukleat, merusak membram sitoplasma bakteri, serta menghambat metabolisme energi pada bakteri. Mekanisme antibakteri flavonoid pada membran sitoplasma yaitu, ion $\mathrm{H}^{+}$ flavonoid akan menyerang gugus fosfat sehingga molekul fosfolipida akan terurai menjadi gliserol dan asam fosfat. Hal ini mengakibatkan fosfolipida tidak mampu mempertahankan bentuk membran sitoplasma menyebabkan keluarnya metabolit penting sehingga pertumbuhan bakteri akan terhambat (Yahya, 2016).

Mekanisme kerja saponin sebagai antibakteri adalah menurunkan tegangan permukaan sehingga mengakibatkan naiknya permeabilitas atau kebocoran sel dan mengakibatkan senyawa interseluler akan keluar berdifusi melalui membran luar dan dinding sel yang rentan kemudian mengikat membran sitoplasma sehingga mengganggu dan 
mengurangi kestabilan membran sel. $\mathrm{Hal}$ ini menyebabkan sitoplasma bocor keluar dari sel yang mengakibatkan kematian sel (Nuria dkk, 2009).

Tanin merupakan senyawa aktif metabolit sekunder yang diketahui mempunyai beberapa khasiat yaitu sebagai astringen, anti diare, anti bakteri dan antioksidan. Tanin merupakan komponen zat organik yang sangat kompleks, terdiri dari senyawa fenolik yang sukar dipisahkan dan sukar mengkristal, mengendapkan protein dari larutannya dan bersenyawa dengan protein tersebut (Desmiaty et al., 2008).

Triterpenoid mempunyai mekanisme antibakteri dengan cara pengrusakan membran sel bakteri. Kerusakan membran sel bakteri dapat terjadi ketika senyawa aktif antibakteri bereaksi dengan sisi aktif dari membran atau dengan melarutkan konstituen lipid dan meningkatkan permeabilitasnya. Membran sel bakteri terdiri dan fosfolipid dan molekul protein. Adanya peningkatan permeabilitas maka senyawa aktibakteri dapat masuk ke dalam sel dan dapat melisis membran sel atau mengkoagulasi sitoplasma dari sel bakteri tersebut (Mayanti dkk. 2005).

\section{KESIMPULAN}

Berdasarkan penelitian yang telah dilakukan dapat disimpulkan bahwa ekstrak etanol daun nangka (Artocarpus heterophyllus Lamk.) memiliki potensi dalam menghambat pertumbuhan bakteri Staphylococcus aureus dengan konsentrasi 500 $\mathrm{mg} / \mathrm{ml}$ memiliki zona hambat paling besar yaitu 10,8 $\mathrm{mm}$.

\section{DAFTAR PUSTAKA}

Desmiaty, Y.; Ratih H.; Dewi M.A.; Agustin R. (2008). Penentuan Jumlah Tanin Total pada Daun Jati Belanda (Guazuma ulmifolia Lamk) dan Daun Sambang Darah (Excoecaria bicolor Hassk.) Secara Kolorimetri dengan Pereaksi Biru Prusia. Ortocarpus.

Kusumawati E, Apriliana A, Yulia R., (2017). Kemampuan Antibakteri Eksrak Etanol Daun Nangka (Atrocarpus heterophyllus Lam.) Terhadap Escherichia coli Jurusan Biologi FMIPA Universitas Mulawarman Samarinda.
Mayanti T, Julaeha E, Putri Y.(2011). Isolasi dan karakterisasi senyawa antibakteri dari fraksi etil asetat kulit batang lansium domesticum corr. cv kokossan. Universitas Padjajaran. Fakultas MIPA. Bandung.

Nasution H. Rahmah M.N., (2014). Pengujian antiradikal bebas difenilpikril hidrazil (DPPH) ekstrak etil asetat daun nangka (Artocarpus heterophyllus Lamk) Universitas Muhamadiyah, Pekanbaru, Riau, Indonesia.

Nuria, Maulita dan Cut. (2009). Uji Aktivitas Antibakteri Ekstrak Etanol Daun jarak Pagar (Jatropha curcas L.) terhadap Bakteri Staphylococcus aureus ATCC 25923, Escherichia coli ATCC 25922, dan Salmonella typhi ATCC 1408. Jurnal IImuIImu Pertanian.

Putri Dayu Nirwana, (2002). Uji Aktivitas Antibakteri Ekstrak Metanol Daun Kenikir (Cosmos caudatus Kunth.) Terhadap Bakteri Salmonella typhi Universitas Islam Negeri Maulana Malik Ibrahim Malang.

Sitorus, P. (2018). Obat Herbal Indonesia (Herbal Medicine). Medan: USU Press.

Stark, L. (2013). Staphylococcus aureus - aspects of pathogenesis and molecular epidemiology. Sweden: Linkǒping University.

Suryati Nova, Elizabeth Bahar, iimiawati. (2017). Uji Efektivitas Antibakteri Ekstrak Aloe vera Terdadap Pertumbuhan Escherichia coli Secara In Vitro. Jurnal Kesehatan Andalas.

Yahya, Hilmi. (2016). Pengaruh Air Perasan Jeruk Nipis (Citrus aurantifolia Swingle.) Terhadap Hambatan Pertumbuhan Bakteri Enterococcus faecalis Dominan Pada Saluran Akar Secara In Vitro. Skripsi. Universitas Muhammadiyah Surakarta.

Yulianty, Astrid deasy, Noorhamdani as, Bambang Soemantri., (2013). Uji Efektivitas Ekstrak Kulit Buah Manggis (Garcina Mangostana) Sebagai Alternatif Antibakteri Terhadap Esceriachia Coli Secara In Vitro. Fakultas Kedokteran Universitas Brawijaya.

Yunikasari D, Joko waluyo, Siti murdiyah., (2016). Uji Daya Hambat Ekstrak Etanol Daun Alpukat (Persea americana Mill) Terhadap Pertumbuhan Bakteri Staphylococcus epidermidis. Prosiding.Universitas Jember. 